\title{
Úlcera labial como signo de presentación de sífilis primaria en paciente con infección por VIH no conocida: a propósito de un caso
}

\section{A lip ulcer as a first sign of early syphilis in a patient with unknown HIV infection: a case report}

\author{
A. Pozo Porta' , I. Iriarte Ortabe2, P. Zaballos Diego ${ }^{4}$, M.A. Morey Mas², \\ J. Collado López', M.J. Pastor Fortea', I. Forteza-Rey Borralleras ${ }^{3}$
}

Resumen: Se presenta el caso de un paciente con úlcera labial cuya apariencia clínica simula un carcinoma escamoso. Sin embargo, una correcta historia clínica y la realización de pruebas complementarias conducen al diagnóstico primario de infección por Treponema pallidum y secundario de seropositividad para VIH. Tras el diagnóstico serológico el tratamiento antibiótico es efectivo para la sífilis.

Concluimos que ante una lesión labial de aspecto ulceroso debe contemplarse un diagnóstico diferencial que incluya el chancro sifilítico y realizar, en el caso de que se confirme, las pruebas complementarias necesarias para descartar infección concomitante por $\mathrm{VIH}$.

Palabras clave: Sífilis; Úlcera labial; VIH.

Recibido: 31 de mayo 2004

Aceptado: 7 de julio 2004

\begin{abstract}
A case report is presented of a patient with a lip ulcer that led to a primary diagnosis of infection through Treponema pallidum and to a secondary diagnosis of HIV seropositivity. The diagnosis was made by serology and the antibiotic treatment was effective for the syphilis.

We conclude that when faced by a lesion of the lip that has an ulcerous appearance, a differential diagnosis should be contemplated that includes a syphilis chancre and, if this is confirmed, the necessary complementary test should be carried out in order to rule out concomitant HIV infection.
\end{abstract}

Key words: Syphilis; Lip ulcer; HIV.
1 Médico residente.

2 Médico adjunto.

3 Jefe de Servicio.

Servicio de Cirugía Oral y Maxilofacial. Hospital Universitario Son Dureta.

Palma de Mallorca, España

4 Médico adjunto. Servicio de Dermatología. Hospital de Santa Tecla, Tarragona, España

Correspondencia:

A. Pozo Porta

c/ Andrea Doria 55.

07014 Palma de Mallorca, España.

E-mail: albertpozoporta@hotmail.com 


\section{Introducción}

La sífilis ha reaparecido en los últimos años en relación con el virus de la inmunodeficiencia adquirida $(\mathrm{VIH})$. Cabe pensar pues en ella ante lesiones orales, ya que es la cavidad oral la primera localización extragenital en la infección por Treponema pallidum, y en la posibilidad de manifestaciones atípicas, dado que la infección por el virus del VIH puede afectar el curso natural de la sífilis e incluso su respuesta al tratamiento.

Nuestro caso intenta destacar el diagnóstico de infección por Treponema pallidum a partir de una lesión labial y como ésta sirve de signo para un posterior estudio que confirma el diagnóstico secundario de infección por VIH. Señala también la importancia del diagnostico diferencial de esta lesión que incluye el carcinoma escamoso de labio y la infección por herpes.

\section{Caso clínico}

Varón de 38 años que acude remitido por su médico por urgencias para valoración de lesión en labio inferior de un mes y medio de evolución.

Presenta como antecedentes personales: hepatitis no filiada, amigdalectomía en la infancia, y hábito homosexual.

Hace un mes y medio el paciente nota la aparición de una lesión en labio inferior que mejora parcialmente tras tratamiento con aciclovir por parte de su médico de cabecera pero empeora al dejarlo. El paciente refiere asimismo lesiones en escroto y pie izquierdo de aparición reciente.

A la exploración física presentaba una lesión ulcerada de $2 \mathrm{~cm}$ en el lado izquierdo del bermellón del labio inferior, de base indurada, no dolorosa a la palpación (Fig. 1). El cuello era negativo para adenopatías. No se observaron otras lesiones en el área de cabeza y cuello. Simultáneamente presentaba en el pie izquierdo una lesión de aspecto ulcerado de $0,5 \mathrm{~cm}$ interdigital (Fig.2), superficie lisa y exudado seroso y múltiples máculas de menor tamaño, redondeadas, de color rojo cobre e indoloras al tacto en la planta del mismo pie (Fig. 3). Por último, mostraba en el escroto varias lesiones de pequeño tamaño (menores de $0,5 \mathrm{~cm}$ ) de aspecto ulcerado en distintas fases de

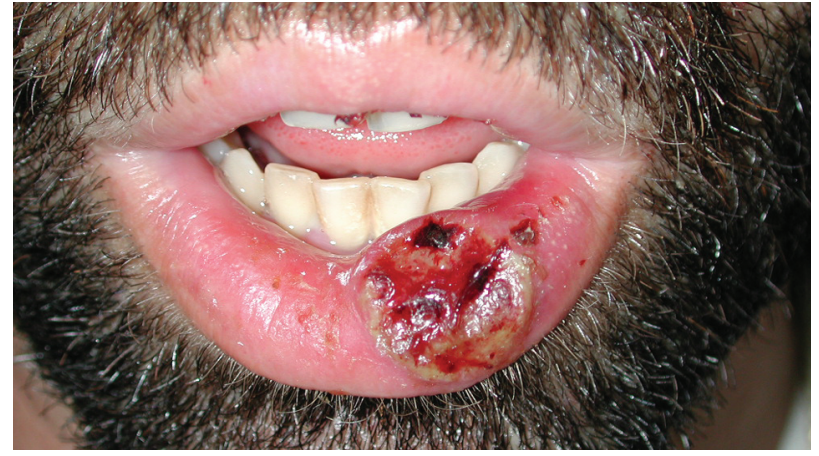

Figura 1. Úlcera labial motivo de la consulta. Figure 1. Lip ulcer leading to the consultation.

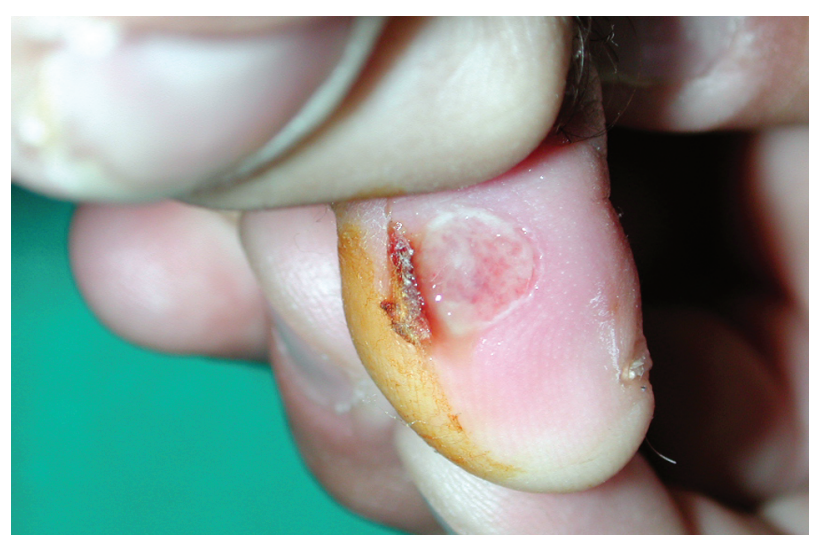

Figura 2. Úlcera interdigital pie izquierdo.

Figure 2. Interdigital ulcer on left foot.

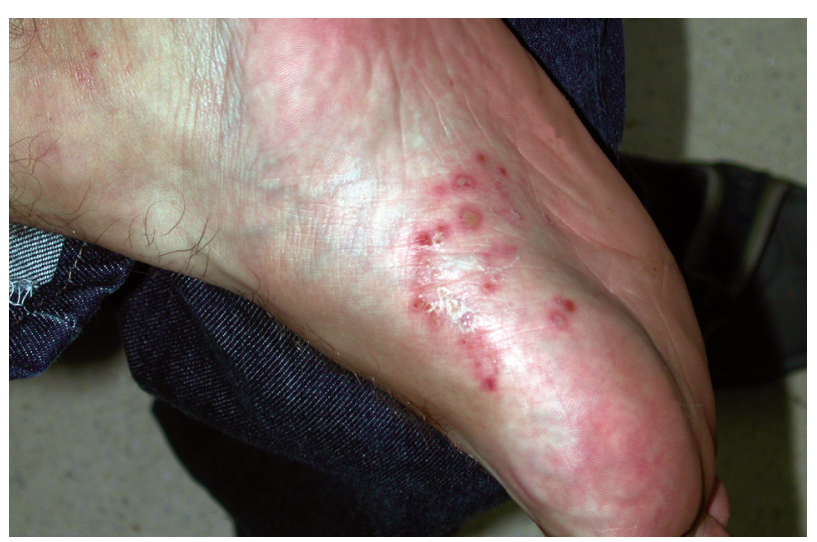

Figura 3. Manchas plantares. Figure 3. Patches on the sole of the foot.

\section{Introduction}

Syphilis has reappeared over the last years in conjunction with the Human Immunodeficiency Virus (HIV). This should therefore be taken into account with regard to oral lesions, as the oral cavity is the first extragenital location in Treponema pallidum infection, together with the possibility of atypical manifestations, given that infection by the HIV virus can affect the natural course of syphilis and even the response to treatment.

The case presented is aimed at highlighting the diagnosis of Treponema pallidum infection based on a lip lesion and how this should serve as a sign for further study in order to confirm the secondary diagnosis of HIV infection. It shows the importance of a differential diagnosis of this lesion that includes squamous cell carcinoma of the lip and herpes infection.

\section{Case Report}

A 38-year-old male was sent to the Emergency Unit by his doctor for an evaluation of a lesion on his lower lip that had been evolving for a month and a half.

His personal background included: undetermined hepatitis, a tonsillectomy during his youth, and a homosexual habit.

For a month and a half the patient had noticed the appearance of a lesion on his lower lip that had improved partially with the acyclovir treatment prescribed by his GP, but that worsened on stopping it. The patient also referred to lesions on the scrotum and left foot that had appeared recently.

The physical examination revealed an ulcerated lesion measuring $2 \mathrm{~cm}$ on the left side of the lower lip vermilion, with an indurated base, that was not painful to palpation (Fig. 1). 
resolución y dolorosas a la palpación (Fig. 4). El resto de la exploración física estaba dentro de los límites de la normalidad.

Se realizó biopsia de la lesión labial que no fue concluyente y se solicitaron pruebas de laboratorio para el despistaje de infecciones por VHB (AgHBs: negativo, Anti-HBc: positivo, Anti-HBs cuantitativo: >1000 mUl/ml -positivo-), VHC (ELISA-G: negativo), VIH (Inmunoblot: positivo, ELISA IgG: positivo, ELISA (2 ${ }^{\text {a }}$ técnica): positivo, Carga (Chiron): 3,69 Log copias de VIH-RNA/ml, Población linfocitaria (CD 3+): CD 4: 43\%, CD 8: 56\%, Cociente CD 4/CD8: 0,77, CD 4 valores absolutos: $762 \mathrm{cel} / \mathrm{ul}, \mathrm{CD} 8$ valores absolutos: $992 \mathrm{cel} / \mathrm{ul}$ ), sífilis (RPR: 1/64 Positivo. TPHA: Positivo. ELISA captura G: Positivo (Test treponémico)) y tuberculosis (Mantoux: negativo). No se realizó estudio complementario de LCR dado la ausencia de sintomatología neurológica y corta evolución.

Con el diagnóstico de sífilis en paciente portador de $\mathrm{VIH}$, el paciente fue tratado con una monodosis de Penicilina G Benzatina (2,4 mill U) i.m. con resolución completa de las lesiones en dos semanas (Fig. 5 y 6). El control serológico a los 6 meses confirmó la resolución del cuadro.

\section{Discusión}

La sífilis o lúes es una infección sistémica de evolución crónica y distribución mundial transmitida por contacto sexual y ocasionada por un espiroqueta denominada Treponema pallidum (TP).1,2

Tras las epidemias de las últimas décadas relacionadas con la llamada «revolución sexual» (homosexual, la última), se observó en los ochenta una tendencia a la disminución de los casos de sífilis debido en general a una modificación de la conducta sexual debida a la aparición del virus del VIH. ${ }^{3}$ Sin embargo, la lúes vuelve a reaparecer en la actualidad como un problema de salud público considerable. ${ }^{4}$ Su incidencia, al igual que la de otras enfermedades de transmisión sexual (ETS), ha aumentado debido, según distintos estudios epidemiológicos, al virus de la inmunodeficiencia adquirida habiendo sido descrita una prevalencia de hasta un 70\% de esta afección en pacientes portadores del VIH.4,6 Se ha documentado también como la sífilis supone un factor de riesgo para la

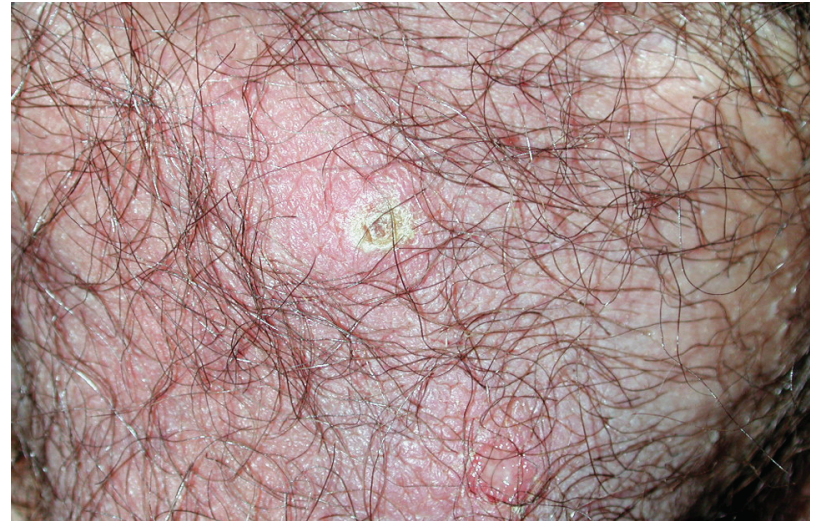

Figura 4. Lesiones escrotales.

Figure 4. Lesion on the scrotum.

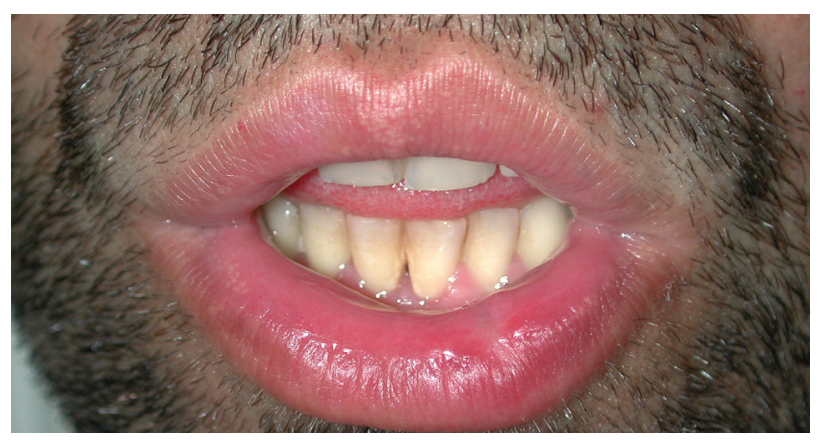

Figura 5. Resolución lesión labial.

Figure 5. Lip lesion once resolved.

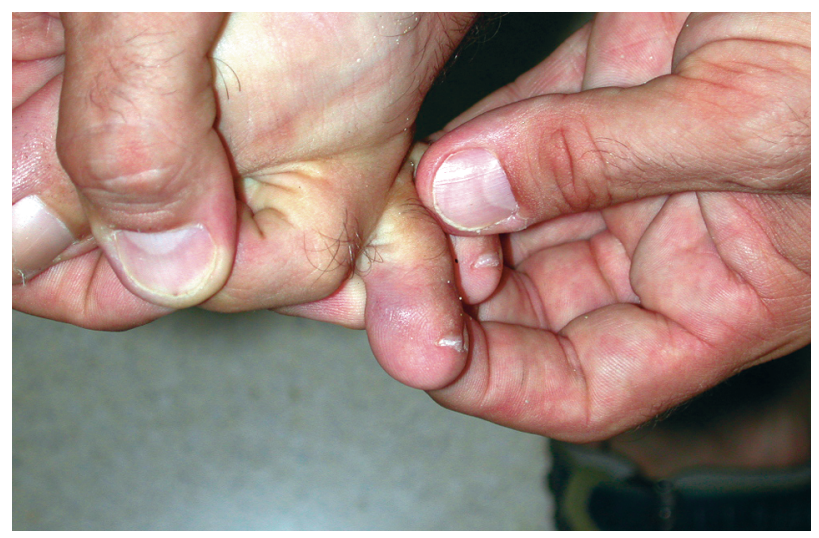

Figura 6. Aspecto úlcera interdigital tras tratamiento.

Figure 6. Appearance of interdigital ulcer following treatment.

There were no neck adenopathies and the intraoral examination was negative. No other lesions were observed in the area of the head and neck. He had a simultaneous interdigital lesion on the left foot with an ulcerous appearance that measured $0.5 \mathrm{~cm}$ (Fig. 2). It had a smooth surface, a serous exudate and there were numerous smaller sized macules on the sole of the same foot that were round and copper colored and painless to palpation (Fig. 3). Lastly, he had on his scrotum various small lesions (measuring less than $0.5 \mathrm{~cm}$ ) that were ulcerated in appearance and painful on palpation (Fig. 4). The remaining physical examination was within normal limits.

A biopsy was carried out on the lip lesion that was inconclusive and laboratory tests were carried out for infection screening HBV (HbsAg: negative; Anti-HBc: positive; quantitative Anti-HBs: (>1000 $\mathrm{mIU} / \mathrm{ml})$, positive, HCV (ELISA-G: negative), HIV (Immunoblot: positive; ELISA IgG: positive; ELISA (second technique): positive; load (Chiron): 3.69 log copies of HIV-RNA/ml: lymphocyte count (CD+3): $C D 4$ : $43 \%, C D$ 8: 56\%; CD 4/CD8 rate: 0.77 , absolute CD4 count: 762 cells/ul, absolute CD8 count: 992 cells/ul), syphilis (PRP: Positive at 1:64. TPHA; Positive. Captia G ELISA: Positive (treponemal test)) and tuberculosis (Mantoux: negative). A complementary CSF study was not carried out given the absence of neurological symptoms and the short development period.

As the diagnosis was of syphilis in a patient that was carrying HIV, the treatment consisted in penicillin benzathine (2.4 mU) IM, there being complete resolution of the lesions after two weeks (Fig. 5 and 6). The serologic tests at 6 months confirmed the resolution of the symptoms. 
transmisión del VIH.7 Finalmente la infección por el virus del VIH puede afectar el curso natural de la infección y su respuesta al tratamiento. ${ }^{6}$

Conocidas estas estadísticas que relacionan VIH e infección por TP se recomienda que en todos los pacientes con sífilis (u otra ETS) se descarte infección por VIH y que todos los pacientes seropositivos para VIH sigan valoraciones adecuadas para descartar una ETS.

La sífilis dejada a su libre evolución presenta tres estadios claramente distinguibles. En el periodo primario (sífilis primaria) la clínica consiste en la aparición del chancro, las adenopatías regionales y un cuadro de malestar general debido a la diseminación del Treponema desde el lugar de inoculación al torrente sanguíneo. En el secundario (sífilis secundaria) aparece un nuevo cuadro constitucional, la afectación ganglionar es generalizada y aparecen lesiones cutáneas diseminadas conocidas como sifílides. Estas últimas son de dos tipos: maculares (de aparición más temprana) o papulares que en su localización palmoplantar son la lesión más característica de este período. Finalmente en el estadio terciario se produce una afectación generalizada que puede afectar a cualquier órgano de la economía, describiéndose en este período los característicos gomas o la afectación del sistema nervioso entre otros. ${ }^{1,2}$

En los pacientes con infección intercurrente por $\mathrm{VIH}$, tales estadíos no son tan claramente distinguibles solapándose unas veces entre ellos y tomando aspecto clínico distinto en otras.8,9 Así por ejemplo, la sífilis en pacientes infectados por el VIH se presentan con más frecuencia en estadio secundario y aquellos con sífilis secundaria es más probable que tengan chancros. ${ }^{10}$ Del mismo modo se están describiendo casos de neurosífilis en periodos más tempranos a lo que corresponde y en mayor frecuencia siendo una de las principales complicaciones que aparece en la coinfección VIH-sífilis. ${ }^{11}$ En este marco es importante también para el clínico ser consciente de las distintas manifestaciones sistémicas posibles de la lúes y amparar, dentro de estas, la afectación oral, ${ }^{12}$ pues existen distintas enfermedades que afectan a los pacientes con $\mathrm{VIH}$ que pueden dar clínica a nivel de la cavidad oral. En el caso concreto de la sífilis la localización oral es la primera extragenital.1,2

En el caso del presente artículo y ante la presencia de la lesión labial que condujo al paciente a solicitar consulta en nuestro servicio, el diagnóstico diferencial se realizó, una vez descartado por lo florido de la lesión el diagnóstico inicial de úlcera labial por herpes, entre una lesión de tipo carcinoma y la que resultó ser, de sífilis labial, de tratamiento no quirúrgico. Cabe enfatizar cómo a través del diagnóstico inicial de la enfermedad de transmisión sexual se contemplaron al mismo tiempo los estudios que condujeron al segundo diagnóstico de seropositividad para VIH lo cual permitió un tratamiento anti-retroviral anterior.

Las técnicas de diagnóstico habituales en la sífilis se dividen en aquellas directas basadas en la visualización de la espiroqueta al microscopio e indirectas o serológicas que a su vez se diferencian en pruebas no treponémicas (o reagínicas) -RPR (rapid plasma reagin), VDRL (venereal disease research laboratory) como más utilizadas- que miden los anticuerpos frente a sustancias producidas por los tejidos dañados y treponémicas -FTA-ABS (fluorescent treponemal antibody absortion) y TPHA (Treponema pallidum hema-

\section{Discussion}

Syphilis or lues is a chronic systemic infection found worldwide that is transmitted through sexual contact. It is caused by a spirochete called Treponema pallidum (TP), 1,2 which is a slender spiral organism with a width of $0.25 \mathrm{~mm}$ and a length of 5 to $20 \mathrm{~mm}$. It can be identified by its characteristic morphology and motility when observed by dark field microscopy or with fluorescence techniques. It does not grow in a laboratory medium, and it rarely reproduces itself in tissue cultures, nor will it survive for long outside the human body. It penetrates through mucosa and skin reaching the regional lymphatic nodes in a few hours, spreading through the organism rapidly.

Following the epidemics over the last few decades in conjunction with the so called «sexual revolution» (from the end on the 80s and during the 90s the incidence of primary and secondary syphilis doubled in black Americans due to cocaine abuse and prostitution). At the end of the nineties a decrease in the syphilis trend was observed due generally to a modification in sexual conduct as a result of the appearance of the HIV virus and to the intensive measures adopted by the public health services. ${ }^{3}$ However, lues is now reappearing posing a considerable problem for public health. 4 Its incidence, like other sexually transmitted diseases (STD), has increased due, according to different epidemiological studies, to acquired immunodeficiency virus 5,6 with a prevalence described of up to $70 \%$ regarding this affection in patients carrying HIV. ${ }^{4,7}$ Syphilis as a risk factor in the transmission of HIV has also been documented. 8,9 Finally, HIV virus infection can affect the natural course of the infection and its response to treatment. ${ }^{7}$

Bearing in mind the statistics that connect HIV with TP infection, ruling out HIV infection is recommended in all patients with syphilis (or any other STD) together with proper assessment of all HIV seropositive patients in order to rule out STD.

Syphilis left to develop freely has three clearly distinguishable stages. In the primary stage (primary syphilis) the clinical presentation consists in the appearance of a chancre, regional adenopathy and general symptoms of discomfort due to the dissemination of the Treponema from the inoculation area into the blood stream. In the secondary stage (secondary syphilis) a new constitutional set of symptoms appear. The nodes are affected generally and disseminated cutaneous sores known as syphilids appear. These can be of two types: macules (that appear earlier on) or papules that, being located on the palms or soles, are the most characteristic lesion during this period. Finally, in the tertiary stage the body is affected generally and any organ may be affected. During this period, among the symptoms that appear are the characteristic gummas and nervous system disorders. ${ }^{1,2}$

Orally syphilis produces a chancre (red papule that quickly turns into a painful ulcer with a serum-sanguinolent scab), mucosal patches, gummas and associated adenopathies. 
glutination assay) entre otras- que valoran la existencia de anticuerpos frente al TP.1,2 La aplicación de las distintas técnicas tiene sus indicaciones a la vez que limitaciones. Así, por ejemplo, se utiliza el examen directo del exudado para las fases iniciales de la enfermedad si bien puede dar falsos negativos ante la presencia de pocas espiroquetas en la lesión; las pruebas no treponémicas no aseguran sífilis ante su positividad si bien son las ideales para la evaluación de la eficacia de los tratamientos; y las treponémicas son utilizadas para confirmar los resultados positivos, sin embargo no negativizan incluso una vez sanado el enfermo. En conjunto suelen emplearse ambos tipos de pruebas serológicas en suero, plasma o LCR según el estadío o afectación que se sospeche.1,2

En cuanto al diagnóstico de sífilis en pacientes infectados por $\mathrm{VIH}$ puede ser más complicado debido a las falsas reacciones serológicas, 13,14 y las presentaciones atípicas de lúes en la presencia de infección por VIH. ${ }^{8,10}$

El tratamiento de la sífilis depende del estadio de la enfermedad siendo en los más precoces suficiente con una única dosis de 2,4 millones de unidades de penicilina $G$ benzatina por vía intramuscular. En sífilis tardías (de más de un año de evolución) o de duración desconocida se recomienda la misma dosis repetida una vez por semana durante tres semanas. Finalmente, para el tratamiento de la neurosífilis debe añadirse una pauta endovenosa previa a la anterior. ${ }^{1,2}$ Para los pacientes alérgicos a la penicilina existen pautas distintas que utilizan la ceftriaxona, la eritromicina o las tetraciclinas.

Se ha considerado un mayor índice de fracasos en pacientes VIH positivos, ${ }^{13-15}$ sin embargo se consideran útiles las pautas clásicas para el tratamiento de inicio. En última instancia son indispensables los controles clínicos y serológicos cada pocos meses hasta el año o los dos años en los casos de mayor evolución. ${ }^{1,2}$ Es indispensable también identificar cualquier contacto sexual del paciente en los últimos tres meses en los casos precoces y hasta el año en los más evolucionados. ${ }^{1,2}$

\section{Bibliografía}

1. Sherris JC, Champoux JJ, Corey L, Neidhard EC, Plorde JJ, Ray CG y Ryan KJ. Microbiología Médica. Barcelona: Ediciones Doyma; 1993;p.p.1000-5.

2. Pumarola A, Rodríguez-Torres A. García-Rodríguez JA. Microbiología y Parasitología Médica. Barcelona: Editorial Salvat; 1987;p.p.535-41.

3. Centers for Disease Control and Prevention. Continuing increase of infectious syphilis: United States. MMWR Morb Mortal Wkly Rep 1988;37:35-8.

4. Hook EW III. Syphilis and HIV infection. J Infect Dis 1989;160: 530-4.

5. Quinn TC, Cannon RO, Glasser D, Groseclose SL, Brathwaite WS, Fauci AS, y cols. The association of syphilis with risk of human immunodeficiency virus infection in patients attending sexually transmitted disease clinics. Arch Intern Med 1990; 150:1297-302.

6. Hutchinson CM, Rompalo AM, Reichart CA, Hook EW III. Characteristics of patients with syphilis attending Baltimore STD clinics. Multiple high-risk subgroups and interactions with human immunodeficiency virus infection. Arch Intern Med 1991;151:511-6.

7. Simonsen JN, Cameron DW, Gakinya MN, Ndinya-Achola JO, O'Costa LJ, Karasira $\mathrm{P}$, et al. Human immunodeficiency virus infection among men with sexually transmitted diseases. N Engl J Med 1988;319:274-8.
In patients with intercurrent HIV infection, these stages are not quite so clearly distinguishable as they overlap and the clinical presentation will be altered.10-13 Thus for example, syphilis in patients infected with HIV present with secondary staging more frequently, and those with secondary syphilis are more likely to have chancres. ${ }^{14,15}$ In a similar fashion, cases of neurosyphilis are being reported at earlier stages to those expected and with greater frequency, with this being one of the principal complications that appears when there is HIV-syphilis co-infection. ${ }^{16-18}$ Within this framework it is also important for the clinician to be aware of the different possible systemic manifestations of lues and to be mindful, within these, of abnormal oral conditions ${ }^{19}$ as various diseases can affect patients with HIV that can lead to clinical symptoms at an oral level. In the case of syphilis, the oral cavity is the first extragenital location.1,2

With regard to the case in this article, and in view of the lip lesion that led the patient to seek consultation with our service, the differential diagnosis was made, after ruling out the initial diagnosis of a lip ulcer due to herpes (as the infection was so florid), of either a lesion of a carcinoma type or what turned out to be, syphilis of the lip, that required nonsurgical treatment. We should emphasize that due to the initial diagnosis of a sexually transmitted disease, studies leading to the second diagnosis of HIV seropositivity were considered that permitted prior anti-retroviral treatment.

The usual diagnostic techniques for syphilis are divided into those that are direct, and based on the visualization of the spirochete under the microscope, and those that are indirect or serological techniques. These in turn are differentiated into non-treponemal (or reaginic) RPR (rapid plasma reagin) VDRL (venereal disease research laboratory), that are the most used, and which measure antibodies to the substances produced by damaged tissue, and treponemal tests such as FTA$A B S$ (fluorescent treponemal antibody absortion) and also TPHA (Treponema Pallidum hemaglutination assay) that assess the existence of antibodies to TP. 1,2,20 The application of different techniques has its indications as well as its limitations. Thus, P.E. is used in the direct examination of the exudates during the initial phases of the illness, although it can give false negatives if there are only a few spirochetes in the lesion; with the non-treponemal tests syphilis is not guaranteed when positive, although these are the best tests for evaluating treatment efficiency; and the treponemal tests are used for confirming positive results, however, they do not become negative even after the patient has been cured. Both types of serological tests tend to be carried out together using serum, plasma or CSF depending on the staging or on the suspicions as to how affected the patient is. 1,2

With regard to the diagnosis of syphilis in patients infected by HIV, this can be more complicated due to false serological reactions ${ }^{21-26}$ and to the atypical presentation of lues when there is HIV infection. 10,14,15

The treatment required for syphilis depends of the stage of the disease. Penicillin is the drug of choice for all stages 
8. Hutchinson CM, Hook EW, Shepherd M, Verley J, Rompalo AM. Altered clinical presentation of early syphilis in patients with human immunodeficiency virus infection. Ann Intern Med 1994;121:94-9.

9. Musher DM, Hamill RJ, Baughn RE. Effect of human immunodeficiency virus (HIV) infection on the course of syphilis and on the response to treatment. Ann Intern Med 1990;113:872-81.

10. Radolf JD, Kaplan RP. Unusual manifestations of secondary syphilis and abnormal humoral immune response to Treponema pallidum antigens in a homosexual man with asymptomatic human immunodeficiency virus infection. / Am Acad Dermatol 1988;18:423-8.

11. Sands M, Markus A. Lues maligna, or ulceronodular syphilis, in a man infected with human immunodeficiency virus: case report and review. Clin Infect Dis 1995;20:387-90.

12. Manton SL, Egglestone SI, Alexander I, Scully C. Oral presentation of secondary syphilis. Br Dent / 1986;160:237-8.

13. Johnson PD, Graves SR, Stewart L, Warren R, Dwyer B, Lucas CR. Specific syphilis serological tests may become negative in HIV infection. AIDS 1991;5:41923.

14. Musher DM, Hamill RJ, Baughn RE. Effect of human immunodeficiency virus (HIV) infection on the course of syphilis and on the response to treatment. Ann Intern Med 1990;113:872-81.

15. Telzak EE, Greenberg MS, Harrison J, Stoneburner RL, Schultz S. Syphilis treatment response in HIV-infected individuals. AIDS 1991;5:591-5. of syphilis. In order to cure syphilis, a plasma level of at least $0.03 \mathrm{UI} / \mathrm{ml}$ for 6 to 8 days is needed. During early staging, a single dose of 2.4 million units of Penicillin $G$ Benzathine via intramuscular injections is sufficient (a satisfactory blood level for two weeks is produced). In late syphilis (cases that have been evolving for over a year) or of unknown duration, the same dose is recommended but repeated once a week for a period of three weeks. Finally, for the treatment of neurosyphilis, endovenous treatment should be included prior to these last doses. ${ }^{1,2}$ In patients with allergies to penicillin, ceftriaxone can be used ( $1 \mathrm{gr}$ IM every 3 days diluted in 3.6 $\mathrm{ml}$ of $1 \%$ lidocaine) or erythromycin or tetracycline $(500 \mathrm{mg}$ taken orally every six hours for two weeks) or doxycyline, but the effectiveness of these drugs is not well defined.

A greater failure rate in syphilis treatment has been observed in HIV positive patients, ${ }^{13,27,28}$ however, the classical guidelines are considered useful for initial treatment. Lastly, clinical and serological checks every few months for a year, or for two if the disease is more advanced is essential. Also essential is the identification of any sexual contact the patient has had three months previously in early syphilis cases, and for a year in those cases that are more advanced.1,2 